С.И.Арифханова, К.М.Убайдумасва

Клеточные реакции в бронхолегочной системе
при обострении хронической обструктивной болезни
легких с кумуляцией пестицидов в организме

НИИ фтизиатрии и пульмонологии МЗ РУз, г. Ташкент

\title{
S.I.Arifkhanova, K.M.Ubaydullaeva \\ Cell bronchopulmonary reactions in patients with pesticide accumulation and exacerbation of COPD
}

\begin{abstract}
Summary
Cell reactions of bronchopulmonary system in COPD exacerbation were investigated in BALF from 182 patients. Patients were divided into 2 groups: with or without pesticide accumulation. Smoking habit was also taken into consideration. We estimated biocide potential of AM using spontaneous and induced NST-test in 4 groups, calculated the stimulation index that revealed several patterns of cell reactions. Chronic excessive activation of AM by smoking, pesticides and/or other risk factors provided hyperresponsiveness of biocide systems of mononuclear monocytes.
\end{abstract}

\section{Резюме}

На материале бронхоальвеолярного лаважа (БАЛЖ) 182 больных изучены клеточные реакции в бронхолегочной системе при обострении хронической обструктивной болезни легких (ХОБЛ). При этом больные были разделены на 2 большие группы без и с наличием кумуляции пестицидов в организме, а также учитывался фактор курения. Определение биоцидного потенциала АМ в спонтанном и индуцированном НСТ-тесте в сравниваемых 4 подгруппах больных, а также вычисление индекса стимуляции выявили ряд закономерностей в клеточных реакциях. Хроническая гиперактивация альвеолярных макрофагов курением, наличием пестицидов в организме и других факторов риска способствуют гиперреактивности биоцидных систем мононуклеарных моноцитов.

Резистентность легких к действию повреждающих факторов представлена механизмами неспецифической защиты и иммунологической реактивности, которые определяются общими и местными гуморальными и клеточными реакциями [1-3]. Система неспецифической защиты органов дыхания включает механические (фильтрация, кашель, мукоцилиарный клиренс) и фагоцитарные (макрофаги и лейкоциты) реакции. Иммунная защита специфична по отношению к антигенам и лежит в основе развития иммунного ответа, направленного на нейтрализацию чужеродного материала в органах дыхания [4].

В патогенезе ХОБЛ большое значение имеет нарушение функции местной защиты в респираторном тракте. Важную роль в развитии заболевания играют нарушение эскалаторной функции мукоцилиарного аппарата и общепризнанные факторы риска: курение, загрязнение и запыленность окружающей среды, профессиональная вредность, гиперреактивность бронхов, острые респираторные вирусные инфекции, генетические факторы (наследственность, $\alpha_{1}$-антитрипсин), особенности климата [5].

В условиях Узбекистана, кроме вышеперечисленных общепризнанных факторов риска, есть факторы, обуславливающие краевые особенности патоморфоза ХОБЛ: высокий процент кумуляции хлорорганических пестицидов в организме населения и запыленность хлопковой и табачной пылью в сельскохозяйственных регионах. Представляется важным провести сравнительный анализ клеточных реакций в бронхо- легочной системе при обострении ХОБЛ у больных с кумуляцией пестицидов в организме и без нее.

\section{Материалы и методы}

Обследованы 182 больных ХОБЛ: 89 мужчин и 93 женщины в возрасте 40-73 лет. Все они были разделены на 2 группы в зависимости от содержания в крови хлорорганических пестицидов: 1-я группа больные ХОБЛ без пестицидов в крови, 2-я группа больные с кумуляцией пестицидов в крови (87 и 95 больных соответственно). Каждая группа включала 2 подгруппы: курящие и некурящие (в 1-й группе 47 и 40, во 2-й группе 58 и 37 больных соответственно).

Проводился комплекс стационарных клинических, лабораторных и инструментальных исследований. Системы внешнего дыхания оценивали методом компьютерной пневмотахометрии на аппаратах Pneumoscop и Flowscrean (Jaeger, Германия), обеспечивающих автоматический анализ показателей структуры легочных объемов (жизненная емкость легких (ЖЕЛ) и форсированная жизненная емкость легких (ФЖЕЛ)), мгновенных максимальных объемных скоростей при выдохе 25, 50, 75 \% ФЖЕЛ $\left(\mathrm{MOC}_{25}, \mathrm{MOC}_{50}, \mathrm{MOC}_{75}\right)$, выраженных в $\%_{\text {долж. }}$

Содержание хлорорганических пестицидов в крови больных ХОБЛ определяли методом газожидкостной хроматографии. Методика определения заключалась в извлечении хлорорганических пестицидов органическими растворителями, очистке экстрактов 
путем распределения между двумя несмешивающимися жидкостями, с дальнейшей очисткой в колонке из окиси алюминия и безводного сернокислого натрия. Определение проводилось на хроматографе с детектором по захвату электронов. Данное исследование было проведено в лаборатории гигиены пестицидов НИИ санитарии и гигиены и профессиональной патологии МЗРУз.

Материалом для изучения клеточных реакций в бронхолегочной системе служила жидкость бронхоальвеолярного лаважа (ЖБАЛ), который получали по общепринятой методике после введения в субсегментарный бронх фракционно 100-300 мл подогретого (до $37^{\circ} \mathrm{C}$ ) стерильного физиологического раствора с последующей его незамедлительной аспирацией. Полученную после объединения всех порций ЖБАЛ фильтровали через 2 слоя марли и центрифугировали при 2,5 тыс. об/мин при 2-4 ${ }^{\circ} \mathrm{C}$ в течение 15 мин. К осадку из клеток добавляли 2 мл среды 199 с $20 \%$ телячьей сыворотки и осторожно ресуспендировали. Количество клеточных элементов подсчитывали в камере Горяева. Жизнеспособность клеток оценивали по поглощению трипанового синего. Из полученного клеточного осадка изготавливали мазки, которые окрашивали гематоксилином и эозином и по Романовскому-Гимза. В оставшейся его части проводили разделение альвеолярных макрофагов (АМ) от других клеточных элементов путем инкубации на предметных стеклах во влажной камере в течение 1 ч при комнатной температуре. В выделенных АМ изучали биоцидный потенциал с помощью восстановления нитросинего тетразолия в спонтанном (с-НСТ) и индуцированном (и-НСТ) вариантах по методу А.Н.Шишкиной [6]. В качестве стимулятора использовали липополисахарид $S$. marcescens-продигиозан ("Мосхимфармпрепарат", г. Москва). В мазках посредством с-НСТ и и-НСТ-тестов подсчитывали долю (\%) НСТ-положительных АМ, по которому судили о степени активации внутриклеточных биоцидных систем. Индекс стимуляции определяли по соотношению показателей с-НСТ и и-НСТ-тестов.

Статистическую обработку результатов исследования и корреляционный анализ проводили с помощью программы Excel.

\section{Результаты и обсуждение}

По результатам исследований при обострении ХОБЛ концентрация клеток в ЖБАЛ колебалась в относительно широких пределах в зависимости от принадлежности больного к группе сравнения от 2 тыс. до 6 млн клеток в 1 мл. В группе пациентов некурящих и без кумуляции пестицидов в крови АМ составляли в среднем до 86 \%. На долю АМ у курящих больных без наличия пестицидов в крови приходились до $50 \%$, а у остальных больных с кумуляцией пестицидов в крови и курящих на долю АМ - до 28 \% клеток.

Доля нейтрофильных лейкоцитов (Нф) у пациентов без наличия пестицидов и некурящих составила в среднем до $20 \%$, тогда как у больных курящих и без пестицидов в крови обнаруживалось до 56 \% Нф. В группе с наличием пестицидов в крови и у курящих количество Нф составляло в среднем до $80 \%$.

Почти у всех больных без кумуляции пестицидов в крови и некурящих проявлялась умеренная способность АМ продуцировать высоко реактивные метаболиты кислорода в с-НСТ-тесте. Показатели с-НСТ-теста у них варьировали от $6 \%$ до $22 \%$ и в среднем не превышали норму (19 \%). За "норму" принимались показатели с-НСТ-теста для здоровых лиц, приведенные в работе Е.Ф.Чернушенко [7]. В основном, у всех больных этой группы АМ были чувствительны к дополнительной нагрузке и под действием продигиозана активнее восстанавливали НСТ.

В группе больных с пестицидами в крови и курящих реактивность АМ в с-НСТ-тесте оказалась самой высокой, почти вдвое выше (от $18 \%$ до 40 \%), чем в предыдущей группе (без наличия пестицидов в крови и некурящих). У пациентов с пестицидами в крови и некурящих показатель с-НСТ-теста в АМ был средним по сравнению с показателями предыдущих двух групп и варьировал от 10 \% до $30 \%$.

Примечательно то, что реактивность АМ в иНСТ-тесте определялась исходным состоянием этих клеток (таблица), так как между показателями с-НСТ и и-НСТ-тестов отмечалась высокая положительная корреляционная взаимосвязь $(r=0,86$, $p<0,01)$. При этом процент активных клеток в популяции АМ не зависел от ее численности. Однако содержание Нф в БАЛЖ больных с обострением ХОБЛ в изучаемых подгруппах напрямую зависело от исходной биоцидной активности популяции АМ и ее способности отвечать на дополнительный стимул (продигиозан). Между абсолютными показателями активности АМ в с-НСТ-тесте и абсолютным содержанием Нф в БАЛЖ была выявлена высокая положительная корреляция $(r=0,77, p<0,01)$.

Существуют противоположные мнения разных исследователей о присутствии и роли в бронхолегочной системе функционально активных макрофагов. Так, по А.Г.Чучалину [8], функционально активные макрофаги в бронхоальвеолярном пространстве способствуют эффективной элиминации полиморфно-ядерных лейкоцитов (Нф) и репарации поврежденной ткани легких. По мнению других авторов [3, 9-11], активация макрофагов приводит к постоянному выделению медиаторов воспаления, усилению притока Нф в легкие, способствующим лизису ими эластического каркаса органа. Известно, что АМ под влиянием микробных и немикробных стимулов синтезируют разные хемоаттрактанты для Нф, среди которых встречаются специфичные (IL-8) и неспецифичные (лейкотриен B4, с5а-фрагмент комплемента, тромбоцитактивирующий фактор) [12]. При этом образование IL-8 может усиливаться активацией эндогенных механизмов синтеза высокореактивных радикалов кислорода [13].

Таким образом, особенности клеточных реакций в воздухоносных путях больных ХОБЛ зависят от 
Показатели НСТ-теста до и после стимуляции продигиозаном АМ іп vitro у больных при обострении ХОБЛ

\begin{tabular}{|c|c|c|c|c|c|c|c|}
\hline Группа обследованных больных & $n$ & 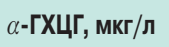 & $\gamma$-ГХЦГ, мкг/л & ДДТ, мкг/л & c-HCT, \% & и-НСТ, \% & Индекс стимуляции \\
\hline $\begin{array}{l}\text { Больные ХОБЛ без наличия пестицидов } \\
\text { в крови и некурящие }\end{array}$ & 47 & - & - & - & $12,8 \pm 2,3$ & $22,9 \pm 1,9$ & $1,86 \pm 0,22$ \\
\hline $\begin{array}{l}\text { Больные ХОБЛ без наличия пестицидов } \\
\text { в крови и курящие }\end{array}$ & 40 & - & - & - & $15,9 \pm 1,8$ & $31,6 \pm 3,8$ & $1,98 \pm 0,31$ \\
\hline $\begin{array}{l}\text { Больные ХОБЛ с кумуляцией пестицидов } \\
\text { в организме и некурящие }\end{array}$ & 58 & $0,0029 \pm 0,01$ & $0,0022 \pm 0,01$ & $0,0032 \pm 0,03$ & $17,6 \pm 1,4$ & $35,3 \pm 4,2$ & $2,00 \pm 0,18$ \\
\hline $\begin{array}{l}\text { Больные ХОБЛ с кумуляцией пестицидов } \\
\text { в организме и курящие }\end{array}$ & 37 & $0,0031 \pm 0,02$ & $0,0024 \pm 0,01$ & $0,0031 \pm 0,02$ & $19,3 \pm 2,3$ & $42,8 \pm 4,6$ & $2,22 \pm 0,24$ \\
\hline
\end{tabular}

функционального состояния мононуклеарных фагоцитов (АМ-клеток), которые можно в клинических условиях определить посредством с-НСТ и и-НСТтестов. Наши данные свидетельствуют, что факторы длительной активизации макрофагов (в частности длительное курение, кумуляция пестицидов в организме) превращают последние в постоянный источник медиаторов воспаления и приводят к усилению притока полиморфноядерных лейкоцитов (Нф) в легкие. Это способствует поддержанию хронического воспаления, со временем ведущего к лизису их эластического каркаса и развитию эмфиземы легких.

Следовательно, терапия больного ХОБЛ должна быть направлена не только на противомикробное воздействие, но и на дезинтоксикацию, на снятие всех возможных причин, приводящих к гиперреактивности АМ (в том числе курение, пестициды), на санационные мероприятия бронхиального дерева с механическим устранением гиперреактивных АМ и чрезмерного накопления Нф в воздухоносных путях.

\section{Заключение}

1. Особенности клеточных реакций в воздухоносных путях больных ХОБЛ определяются функциональным состоянием биоцидных систем мононуклеарных фагоцитов (АМ).

2. В клинических условиях можно прогнозировать течение и эффективность проводимого лечения болезни путем определения функционального состояния биоцидных систем АМ в БАЛЖ постановкой in vitro c-НСТ и и-НСТ-тестов и вычисления индекса стимуляции.

3. Хроническая гиперактивация АМ курением, пестицидами в организме и другими факторами риска способствует гиперреактивности биоцидных систем мононуклеарных моноцитов, что характеризуется индексом стимуляции выше 1,9 раза.

4. Следствием гиперактивации АМ и накопления нейтрофилов в бронхолегочной системе с выделением высоко реактивных радикалов и ферментов лизиса на фоне нарушения мукоцилиарного клиренса является хронизация воспаления и развитие эмфиземы.

Санация бронхиального дерева от гиперреактивных АМ и нейтрофилов, отказ от курения и защита от других факторов риска (энтеросорбцией, гемосорбцией, плазмаферезом, дезинтоксикацией) могут явиться хорошей патогенетической терапией для больных ХОБЛ с кумуляцией пестицидов в организме.

\section{Литература}

1. Копьева Т.Н., Бармина Г.А., Гробова О.М., Воронина Л.М. Местные механизмы защиты при хроническом воспалении в легких. Арх. пат. 1992; 9: 5-12.

2. Ерохин В.В., Романова Л.К. Клеточная биология легких в норме и при патологии. М.; 2000.

3. Макарова О.П., Шишкина Л.Н., Огиренко А.П. и др. Клеточные реакции в легких при обострении хронических заболеваний органов дыхания. Пульмонология 2001; 2: 63-68.

4. Романова Л.К. Структурные основы иммунной защиты легких здорового человека. В кн.: Клеточная биология легких в норме и при патологии. М.; 2000. 259-268.

5. Черняев А.Л. Хронические обструктивные болезни легких. Клеточная биология легких в норме и при патологии. М.; 2000. 357-377.

6. Шишкина Л.Н., Маянский ДН., Богомолова М.В. Реакция легочных макрофагов крыс на стимуляцию зимозаном. Бюл. эксперим. биологии 1985; 10: 454-457.

7. Чернушенко Е.Ф., Гавриленко Т.И. Функциональное состояние фагоцитирующих клеток бронхоальвеолярного смыва при заболеваниях легких. В кн.: Моделирование и клиническая характеристика фагоцитарных реакций. Горький; 1989. 228-237.

8. Чучалин А.Г. Иммунокоррекция в пульмонологии. М.: Медицина; 1989.

9. Маянский Д.Н. Хроническое воспаление. М.: Медицина; 1991.

10. Романова Л.К., Овчаренко С.И., Младковская Т.Б. и др. Особенности клеточных реакций в легких во время обострения бронхиальной астмы. Пульмонология 1992; 1: 20-26.

11. Chang J.C., Wysocki A., Tchouwong K.M. et al. Effect of Mycobacterium tuberculosis and its components on macrophages and the release of matrix metalloproteinases. Thorax 1996; 51 (3): 306-311.

12. Wilkinson J.R., Howell C.S., Lee T.A. Effects monocyte and macrophage-derived products on granulocyte function in asthma. Int. Arch. Allergy Appl. Immunol. 1989; 90: 64-69.

13. Wozniak A., Betts W.H., Murphy G.A. et al. Interleukin-8 primes human neutrophils superoxide anion production. Immunology 1993; 79: 608-615. 